\title{
The Emergence of Public Relations in Azerbaijan: Issues and Case Studies
}

\author{
ilgar Seyidov \\ Ankara University Faculty of Communication \\ ilqar.seyidov@gmail.com
}

\begin{abstract}
With the dissolution of the Soviet Union, 15 countries have become independent by the 1990's. One of them is Azerbaijan Republic. After the independence, socioeconomic structure of the country has changed drastically. In other words, the new capitalist system has emerged. This new system has restructured all existing fields like education, health, business, media and such. In this period, for the first time, few public relations activities have been conducted by some international companies. Public relations is known as Ictimaiyyetle Elaqeler in Azerbaijan. Within the framework of the current study, the different theoretical base and practical structure of public relations in Azerbaijan are examined by the literature review and the case study analysis. The study aims to find out how the public relations is evolving in the country. In this context as a practical research, the study analyzes two social projects as the public relations practices ("Mobile Dental Clinic" and "Children Helpline") conducted by Azercell Telecom company that was awarded in the category of "Communication and PR Campaign of the Year: Community Relations" of International Business Award- Stevie in 2011. On account of the limited literature and research concerning public relations in Azerbaijan, this study is a premise and directive for the future studies.
\end{abstract}

Keywords: Public relations, Azerbaijan, public relations practices, social projects, case study

...

Makale geliș tarihi: 02.08.2015 - Makale kabul tarihi: 04.02.2016

http://ilefdergisi.org/2016/3/1/

ilef dergisi · @ 2016 • 3(1) • bahar/spring: 53-70 


\title{
Azerbaycan'da Halkla iliş̧kilerin Ortaya Çıkıș: Sorunlar ve Örnek Olay Çalıșmaları
}

\author{
ilgar Seyidov \\ Ankara Üniversitesi iletişim Fakültesi \\ ilgar.seyidov@gmail.com
}

Öz

1990'larda Sovyet Sosyalist Cumhuriyetler Birliği'nin parçalanmasıyla 15 ülke bağımsızlık kazanmıștır. Bunlardan biri olan Azerbaycan Cumhuriyeti Sovyetlerin dağılmasıyla ciddi olarak sosyo-ekonomik bir değișim sürecine girmiștir. Daha açık bir ifadeyle yeni bir kapitalist sisteme geçilmiștir. Bu yeni sistem beraberinde eğitim, sağlık, medya gibi bir çok alanda yeniden yapılandırma da getirmiștir. Bu dönemde ilk kez ülkede bazı uluslararası șirketler tarafından yürütülmüș halkla ilișkiler kampanyalarına rastlanmaktadır. Diğer taraftan kavramsal olarak bakıldığında "Halkla ilișkiler" Azerbaycan dilinde íctimaiyetle Eloqeler șeklinde tercüme edilmektedir. Çalıșma kapsamında Azerbaycan'da halkla ilișkiler alanı hem teorik hem de pratik uygulamalar olarak literatür taraması ve örnek olay incelemeleri ile incelenmektedir. Araștırmanın sorunsalı ülkede gelișen halkla ilișkiler alanın nasıl ve hangi dinamiklerle geliștiği üzerinedir. Bu anlamda özellikle pratiğe dayalı incelemede Azercell Telekom tarafından yürütülmüș olan ve 2011 yılında International Business Award- Stevie tarafından "Yılın En Bașarılı PR Kampanyası" seçilen iki sosyal proje ("Mobil Diș Kliniği ve "Çocuklara Yardım”) halka ilișkiler uygulaması örnekleri olarak ele alınmaktadır. Çalıșma Azerbaycan'da hala gelișmekte olan ve az çalıșılmıș halkla ilișkiler alanı açısından yönlendirici bir kaynak olarak gösterilebilir.

Anahtor Kelimeler: Halkla ilișkiler, Azerbaycan, halkla ilișkiler uygulamaları, sosyal projeler, örnek olaylar http://ilefdergisi.org/2016/3/1/

ilef dergisi · @ 2016 · 3(1) • bahar/spring: 53-70 
Azerbaijan gained its independence on 18 October 1991 by the dissolution of the former Soviet regime. Due to the short story of Azerbaijan as an independent state, public relations is a new and unexplored field. During the Soviet regime, there was a one-party political system and authoritarian rule. Therefore, there were not any democratic media environment and public relations activities within this period. After the independence, the theoretical base and practical structure of public relations emerged and was formed by the process of democratization and privatization policies.

Primarily, the situation of public relations in the country is scrutinized in conformity with the specific principles of global public relations stated by Sriramesh and Vercic. ${ }^{1}$ In this context the country's political, economic and cultural background, and media structure are examined. The connection between these structures and public relations activities are focused on. Within the context of this study, the history, education and professionalization of public relations in Azerbaijan are taken into account and country-specific practices are exemplified.

The study aims to find out how the public relations is evolving in the country and which factors are shaping this area. For this, as a practical 
research two social projects of Azercell Telecom company, which are "Mobile Dental Clinic" and "Children Helpline", are analysed. These projects were awarded in the category of "Communication and PR Campaign of the Year: Community Relations" in International Business Awards- Stevie in 2011. Although it is widely acknowledged that the social responsibility projects and public relations both alike and differ from each other, ${ }^{2}$ in Azerbaijan these CSR activities are accepted as the part of the public relations process. Therefore, it will be focused on the examination of these activities as public relations activities to find out how the public relations is theorized and how it is being implemented practically in Azerbaijan.

\section{Azerbaijan within the Principles of Global Public Relations}

Modern public relations is based on two important elements: mutual communication and collaboration. These concepts originally come from "The Excellence Theory" of public relations ${ }^{3}$. In conformity with the internationalization of business and politics, modern public relations has also become "international" or "global". There are nine generic and five specific principles of global public relations which are also the normative principles of excellent public relations practice. ${ }^{4}$ However, the five specific principles are more suitable to examine the structures of public relations practices in different countries. These are political system, economic background, degree of activism, culture and media system. ${ }^{5}$ The examination of public relations practice in Azerbaijan is dealt as compatible with these principles to analyze the phases of the period, except the degree of activism. Despite the existence of many political (democratization issue), economic (corruption issue), and social (refugee and forced migration) problems, activism has not been sufficiently developed in Azerbaijan. As Kim and Sriramesh ${ }^{6}$ stated $^{2}$ activism has the impact on public relations practice, there is not a remarkable connection between activism and the development of public relations in Azerbaijan context.

\section{Political System}

Political background is one of the most important specific principles in examining the situation of public relations. As we know from the many studies, ${ }^{7}$ political systems have significant power of shaping the public relations practices. Therefore, the political environment is one of the main structures to understand the context of the public relations activities in any countries. 
Azerbaijan is one of the countries located in the Caucasus region. In accordance with the 2003 census data, more than 9 million people live in the country and $91.6 \%$ of the population is the Azerbaijani. The state language is Azerbaijani. The Republic of Azerbaijan is governed by the Constitution adopted by a referendum on 12 November 1995. According to the Constitution, "Azerbaijan State is a democratic, secular, and unitary Republic." ${ }^{8}$ The Government of Azerbaijan Republic is based on the principle of separation of powers: the legislative power is the National Assembly (named as Milli Majlis); the president has the executive authority; and the judicial power is given to the courts. Today, according to the data of the Foreign Ministry of Azerbaijan (MFA), approximately 4000 public and non-governmental organizations are serving in Azerbaijan.

After the independence, Azerbaijan has passed through a difficult sociopolitical process. During the first years of the independence, severe conflicts happened to its neighbors and many people died in Nagorno-Karabakh War, Tragedy of January 20, and Khojali. Thousands of people were exposed to a forced migration. Today, $20 \%$ of the country's land is still under the occupation of Armenia. Since the war conditions still persist between Azerbaijan and Armenia, there is not a relationship between the two.

During the former Soviet regime, the political system was based on the centralized one-party government. There was not a democratic environment in Azerbaijan as in the other former Soviet Republics. What is more, ideological propaganda of the Soviet regime was made in every field of the country. Therefore, the formation of any suitable medium for the public relations practices based on the mutual communication was impossible. ${ }^{9}$ Despite the existence of many problems, Azerbaijan is developing in both political and economic environments. Media and public relations are evolving in parallel with these processes.

\section{Economic Background}

The other basic principle to examine the public relations practice is the economic background. The development of public relations is related to the level of economic development. This also affects the level of relationship between marketing and public relations. ${ }^{10}$ According to Khamis and Toth ${ }^{11}$, "in developed countries public relations is a tool for market competition; in developing nations, it assists the government in rallying its citizens." 
Oil and gas industry plays a fundamental role in Azerbaijan economy. Azerbaijan's 2013 gross domestic product (GDP) was 76 billion dollars. The per capita income reached 7,400\$ in 2013. The industry consisted $63 \%$ of 2013 GDP, the service was $30.2 \%$ and the agricultural sector was about $6.2 \% .{ }^{12}$ Since 1994, the making of agreements on energy resources with international companies has resulted in forming of modern technologies and restructuring of the economic background. ${ }^{13}$

Today, Azerbaijan is growing with the help of oil and gas industry. However, there are many economic problems in terms of the people's livelihood. The transition from the socialist economy to the market economy has negatively influenced the income distribution in the society on account of the inadequate social policies. It has led to the emergence of the explicit difference between the upper and lower class of the society. ${ }^{14}$

Following the independence, the international companies in oil and gas sector were the first organizations conducting public relations practices in the country. With the beginning of the 2000's, local companies and government departments have also started to conduct similar public relations practices. ${ }^{15}$ However, public relations work is less developed in local organizations, excluding some corporate companies. Less development stems from the lack of literature, research and practices in the field. Additionally, financial problems influence the development of public relations in local companies. This issue is broadly discussed in later sections.

\section{Culture}

Sriramesh ${ }^{16}$ stated that "culture affects communication and is affected by it" because public relations basically creates a communication process and communication is the core of culture. In this vein, global public relations also refers to the practicing of public relations within the intercultural level. ${ }^{17}$ In the literature, there are many studies examining the relationship between the cultural values, and public relations practices both in experimentally and theoretically. ${ }^{18}$

Azerbaijan has a unique culture, including the multi-denominational religious structure. The majority of the population is Muslims. Islam is represented in both Sunni and Shia forms in the country. By the law, there is a balanced approach to all the religions. At present there are more than 380 registered religious communities in Azerbaijan. Christianity is the 
second most common belief that is represented by the orthodox, catholic and protestant branches. Besides, there are 3 Jewish communities - Mountain Jews, Ashkenazi Jews and Georgian Jews. ${ }^{19}$

The state language is Azerbaijani; however, Russian remains influential and popular among the people, particularly in Baku, the capital city. Russian is still spoken in everyday life. It is related to the Soviet history of Azerbaijan Republic and the closer trade relations with Russia as well. During the former Soviet regime, Cyrillic alphabet was used. By gaining the independence, the law was adopted for the use of Latin alphabet on 25 December 1991. ${ }^{20}$ Yet the remaining of Russian language influence in Azerbaijan leads to the forming of multilingual public relations work. To exemplify it, there is a requirement to know Russian and English in addition to the native language for the job applications in the public relations field.

\section{Media System}

Mass media is one of the most important principles to examine the situation of public relations practices in countries. As Vercic ${ }^{21}$ indicated, mass media can influence public opinion. Therefore, the media have always been a useful tool for public relations practitioners.

During the Soviet regime, the monotype media was created in the all former Soviet republics as in Azerbaijan under the instructions of the Bolshevik Party. There were only one television channel ("The State Television and Radio Comitee Under the Counsel of Ministers") and one radio station ("Araz" Radio) in Azerbaijan. ${ }^{22}$ During this period, the press was an ideological apparatus of Soviet communism. Soviet communism themes were publicized in the magazines. To be more precise, the media was a propaganda tool, and all the mass media tools were funded by the state. ${ }^{23}$

After the independence, the structure of media changed by both the 1995 Constitution (Article 47 and 50 of the Constitution depend on the freedom of thought, expression, and mass communication) and privatization policy. The private mass media started to appear in this period. During the first decade of the independence, according to the data of the Ministry of Press and Information, media outlets were consisted of 344 newspapers, 86 journals, 25 news agencies and $30 \mathrm{TV}$ and radio stations in Azerbaijan. In the last decade of the 2000's, this number increased to 1830 in total. ${ }^{24}$ With the development of media, advertising sector evolved as well. Local advertising agencies are in the form of small and medium businesses. ${ }^{25}$ 
Today, despite the rapid development of the media in Azerbaijan, the independence of the media still remains problematic. In this context, Enserov $^{26}$ highlighted two factors explicating the reasons of this issue. One of them is the media control inherited from the former totalitarian system. Yet the functioning of the control structure on the media is related to the weakness of the local political culture and the less development of non-governmental organizations. The other factor is about the inadequate legislative and normative base for the social role of mass media in society.

\section{The Development of Public Relations in Azerbaijan}

Public relations is a new and developing field in Azerbaijan. There are many issues about the theoretical base and practical forms of public relations. These are correlated with the underdeveloped public relations education and economic-political factors mentioned before.

In accordance with the literature review, two academic books were published concerning public relations. One of them was authored by Ramil Meherremov. This book, published in 2002, is titled Ictamiyyetle Elaqeler Işi: Public Relations. The other one was written by Rafiq Ismayilov in 2001, named as Ictimaiyetle Elaqeler: Bütün Yollar KIV'den Keçir (- Public Relations: All the Ways Pass through Mass Media). Furthermore, there is not any comprehensive academical study or research examining the public relations in Azerbaijan.

In April 2003, the public relations professionals from the different companies such as Internews Azerbaijan, Mercy Corps International, Baku Interbank Currency Exchange, United Aid for Azerbaijan, Cooperative Housing Foundation, Azerbaijan Young Lawyers Association, AzerNet, PR Consulting, Hatt Research Company and UniBank, founded APRA (Azerbaijan Public Relations Association). The main purpose of APRA has been to research challenges, to exchange best practices and perspectives in the field and to promote public relations in the public administration, voluntary and business sectors in Azerbaijan. ${ }^{27}$ To achieve this, the various seminars have been conducted. Besides, public relations education is not provided at the undergraduate level in any universities. It is taught at the graduate level in some universities, predominantly in the private ones.

As to the practices in Azerbaijan, the first public relations department was established by BP-Amoco (Britisih Petroleum) in 1992. The various activities such as social responsibility projects, humanitarian aids towards 
compulsory refugees, Karabakh War veterans, and orphans were conducted by this department. One of the first departments in the country is another oil company's, Chevron's public relations department founded in 1998. Many public relations activities such as the sponsorships to various festivals and art exhibitions were conducted by its PR department. ${ }^{28}$

\section{The Convergence between Corporate Social Responsibility (CSR) and PR in Azerbaijan}

One of the important features of maintaining an excellent organization is a social responsibility project in terms of the connection with strategic planning. ${ }^{29}$ The social responsibility concept evolved within the business ethics in the 1950 's. However, this concept has become important by the 1980's when the interest emerged in image management of the organization. In this respect, Solmaz ${ }^{30}$ interprets social responsibility as one of the effective methods in brand image development. In fact, the social responsibility project is to build the trust between organizations and the public. ${ }^{31}$

There are many similarities between social responsibility and two-way symmetrical model of public relations. The two-way symmetrical model of public relations establishes a balanced communication based on mutual benefits between organizations and the public. ${ }^{32}$ In terms of being ethical and responsible towards the society, the two-way public relations and the corporate social responsibility are interrelated. ${ }^{33}$ Furthermore, social responsibility contributes to increase public relations performance. To comprehend it in a detailed way, social responsibility projects have a role in reducing conflicts between and maintaining close relations with the stakeholders and the public as well. In doing so, public relations models ensure the forming of communication strategies of the corporate social responsibility. ${ }^{34}$

The corporate social responsibility as a notion is new to Azerbaijan. The perception of CSR differs from those in European countries, for instance, many companies except banks, telecommunications, and oil companies consider the CSR as charitable activities. ${ }^{35}$ The lack of information and conceptual basis in the fields of both CSR and public relations leads to understanding and conducting the social responsibility projects and public relations activities in a similar manner. These practices are usually carried out by the same department of the companies. 


\section{Two Case Studies: "Mobile Dental Clinic" and "Children Helpline" Social Projects}

The case study analysis is a research method which includes collecting data about an event or the events and preparing a report ${ }^{36}$. According to Cohen et al. ${ }^{37}$, "a case study is a specific instance that is frequently designed to illustrate a more general principle." It enables us to understand the theoretical ideas more clearly by focusing on a selected example or a few samples. On the other hand, Merriam ${ }^{38}$ defines a case study as an in-depth analysis of a bounded system. In line with her thinking, the phenomenon we are studying on must be intrinsically bounded to be a case. This method is used in various fields and situations to examine the contextual basis of individual, group, organizational, social, political and related phenomena. Case study is preferred by the various disciplines such as psychology, sociology, political science, social work, economics and so forth. ${ }^{39}$

In this study, two social projects are selected to be analyzed as the case studies. These samples allow us to get information about how both the social responsibility and especially public relations practices are carried out in Azerbaijan. These social responsibility projects have been conducted by one of the biggest telecommunication company, Azercell Telecom MMC in Azerbaijan. The projects were awarded for the best public relations campaign of the year in International Business Awards, Stevie in 2011.

The "Mobil Dental Clinic" project (Mobil Diş Klinikasl) has been carried out since 2009. The aim of the project is to provide dental care to the children living in various orphanages. The "Mobil Dental Clinic" is a minibus equipped with modern dental equipments and treatment services (Figure 1). For the purpose, the minibus travels many orphanages in the country throughout the year. ${ }^{40}$

The project has been run by Ufuq, a charitable society. To date, more than 3000 children living in 18 children's institutions in different regions and a refugee camp have been examined and treated. In line with the campaign, many toothbrushes and toothpastes provided by Proter\&Gamble have been given to the children. This social project has attracted a great attention and praised in the traditional and social media. Particularly, the photo of the medical equipments inside the mobile minibus has been shown in the news frequently (Figure 2). 


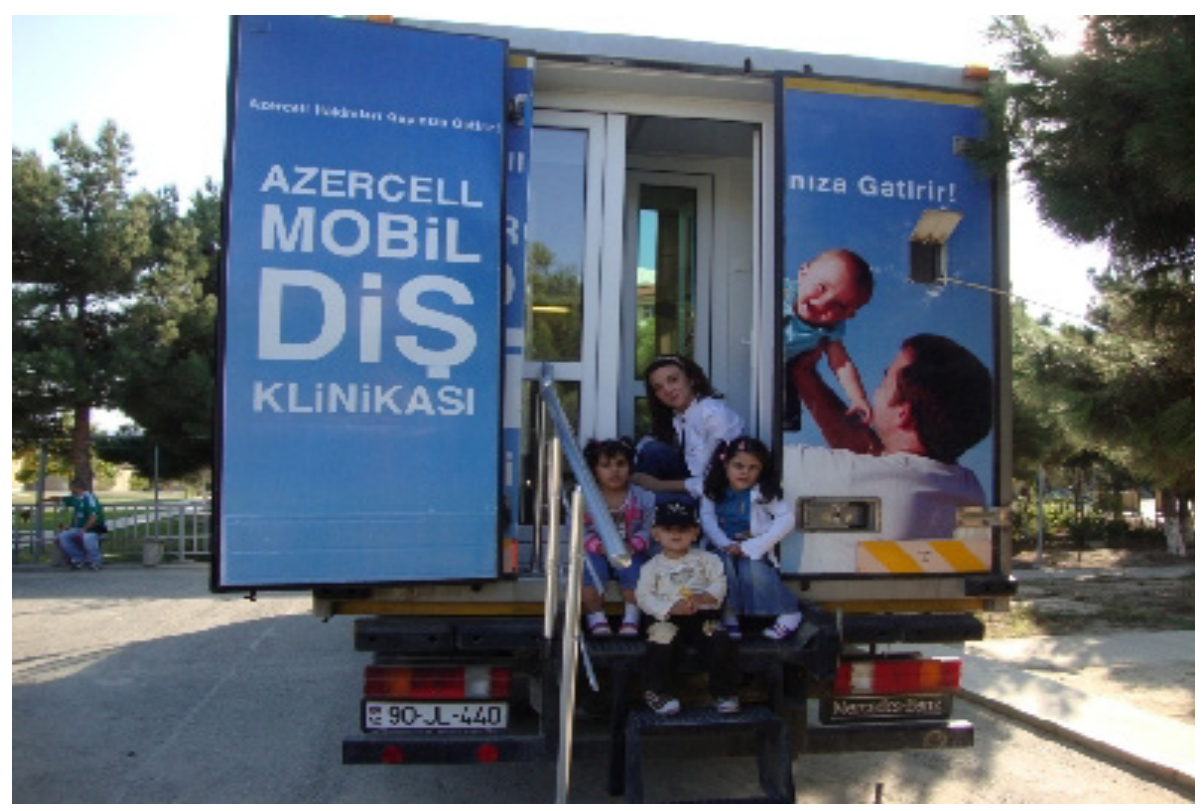

Figure 1. Mobile Dental Clinic Minibus.

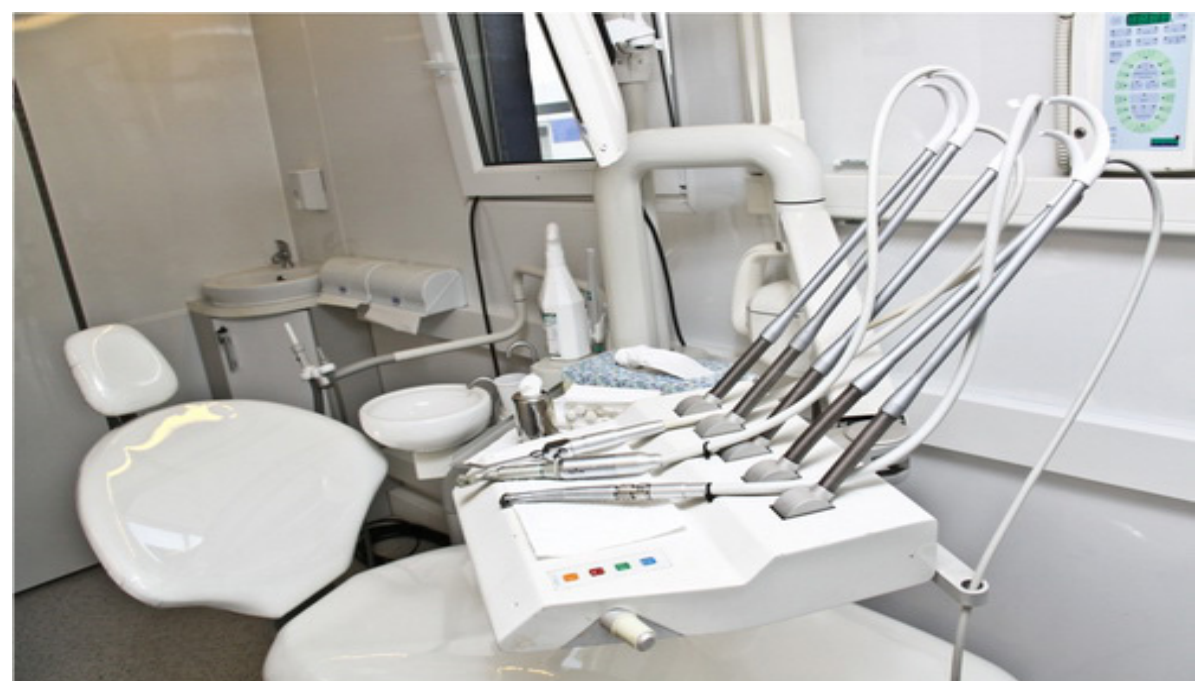

Figure 2. The Dental Equipment in Minibus

There is also information about the campaign activities on the social media link (on Facebook) of Azercell Company. However, there is not any project-specific social media or website link to get comprehensive information about the campaign. It is only available for reaching the details concerning the project in media reports, and on the Web applications of Azercell Company. 


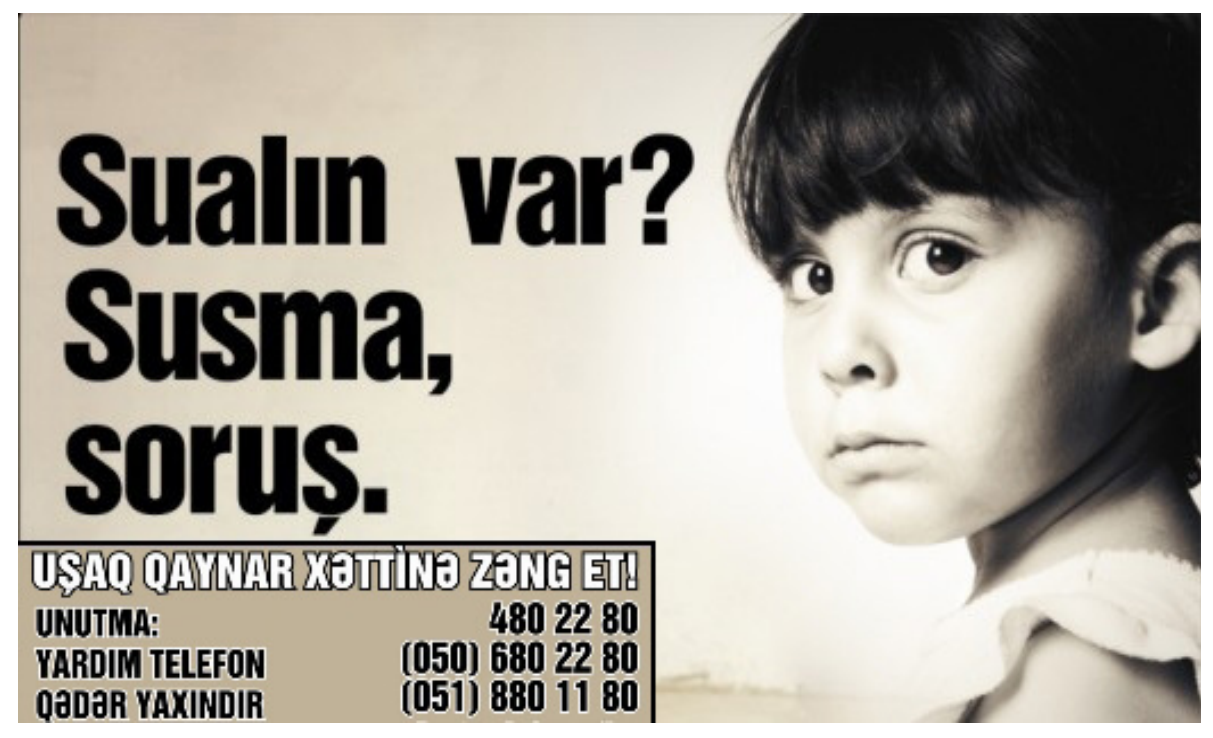

Figure 3. Promotional Ad of Children Helpline

The other campaign which is accessible to a wider audience is the "Children Helpline" project. This project has been conducted since 2010. The campaign is run by Reliable Future Youth, the non-governmental, charity organization. The project is also supported by the office of UNICEF, Save the Children, World Vision, and the Ministry of Education. The aim of the project is to provide psychological help to the children suffering from abuse, violence, and psychological problems. Four different telephone numbers can be used for the calling and the lines are open $7 / 24 .{ }^{41}$ All the calls are toll-free. "Do you have a question? Then ask" is one of the most used slogans in the promotional ads (Figure 3).

The other most commonly used slogan in the ads is; "Do you have problems in communicating with your peers? Call the Children Helpline" (Figure 4). By using this slogan, it is shown that within the scope of this campaign, the calls are available for not only the parent-child relationship problems, but also the social-psychological issues of teenagers with their peers.

According to the data on the website of Azercell company, more than 6000 calls were answered and support provided. More information about the project can also be accessed on the project's website. ${ }^{42}$ There are topics including parent-child relationships, parental restrictions and prohibitions, the teacherstudent conflicts, abuse, aggression in children, and communicative methods 


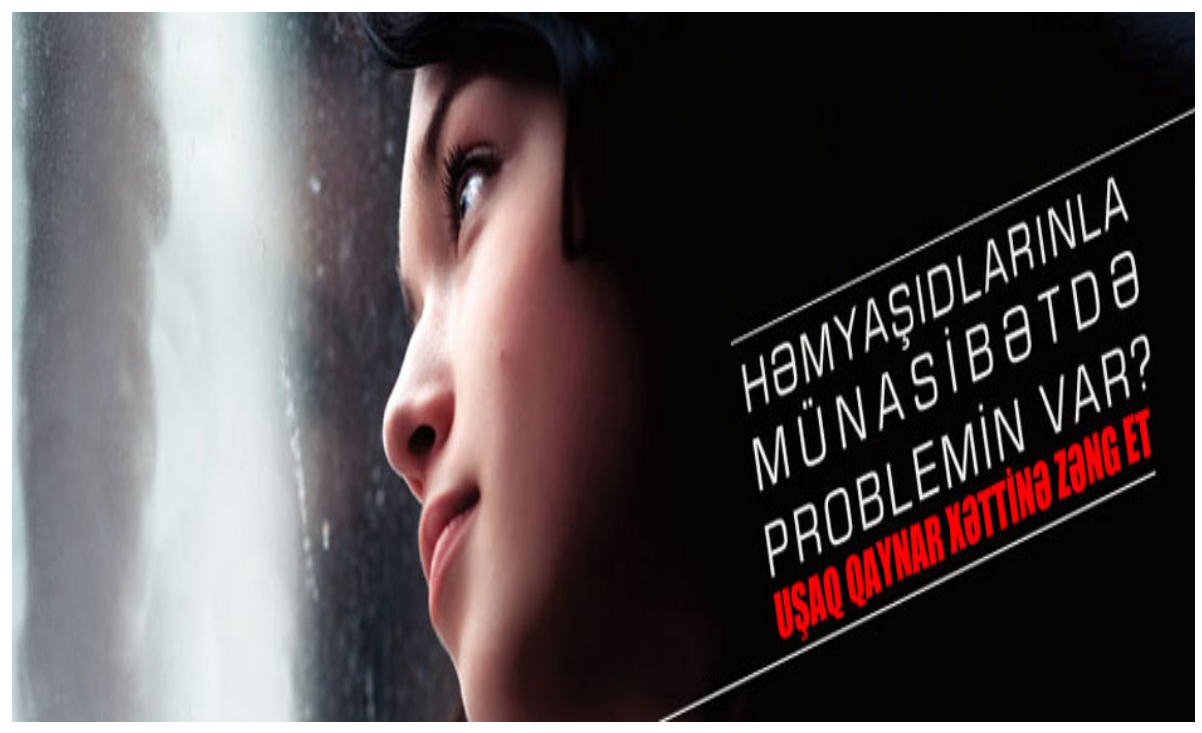

Figure 4. The Promotional Ad of Children Helpline.

available on the website. There is also a useful guide on the website to learn how to reach the required sections.

Within the scope of promotional activities, the campaign posters are used on the buses by the support of the Transport Ministry of Azerbaijan Republic. What is more, there is an active Facebook link of the campaign. Many training sessions held in rehabilitation centers, schools and so forth concerning sociopsychological issues are announced there in order to reach more audiences.

\section{Conclusion}

In accordance with the current research, it is seen that public relations is developing as a profession and a communication tool in Azerbaijan. However, most of the main issues still remain problematic. One of them is the discrepancy between the development of theory and practice. On the one hand, the public relations becomes an important field in parallel with increasing of public relations activities. On the other hand, the theoretical basis is not sufficiently developed due to the lack of academic studies. This is related fundamentally to the situation of public relations education in the country. To be clear, there is not a public relations course in any university, especially in the state universities, and the existing courses are only being taught at the graduate level. 
As to the professionalization of public relations in Azerbaijan, language factor has to be taken into account: Russian is still widely spoken language along with Azerbaijani. Furthermore, due to the existence of many multinational companies in the country, English is the other language that is demanded in the job applications. This leads to the emergence of multilingual public relations job.

Within the scope of the study, the other significant finding is the convergence between CSR and PR in Azerbaijan. Due to the similarities between the practices of corporate social responsibility and public relations, they are intertwined in the country. The first public relations departments in Azerbaijan conducted social responsibility campaigns. It stems from the economic background, political system and cultural structure of Azerbaijan as stated before.

Briefly, the current study focused on the examination of public relations context in Azerbaijan. Within the scope of this limited research, it was revealed that a conceptual study concerning public relations had not been done in the literature. Besides, there are few studies addressing the public relations context in the country. In this respect, it is hard to find out what kind of public relations model is used in the country context. More comprehensive and practical researches must be carried out in order to identify the suitable public relations model. This study can be a guide for the future works oriented with the public relations in Azerbaijan. 


\section{Notes}

1 Krishnamurty Sriramesh and Dejan Vercic, "A Theoretical Framework For Global Public Relations Research and Practice," in The Global Public Relations Handbook, ed. Krishnamurty Sriramesh and Dejan Vercic. (New York: Routledge, 2009).

2 Cynthia E. Clark, "Halkla İlişkiler ve Kurumsal Sosyal Sorumluluk Arasındaki Farklılık: Bir Analiz," Translated by Hanife Guz, in Halkla İlişkilerde Seçme Yazılar: Alana İlişkin Bir Derleme, ed. Hanife Guz and Sema Becerikli. (Ankara: Alban Tanıtım, 2004); Leeora D. Black, and J. E. Charmine Hartel, "The Relationship Between Corporate Social Responsibility and Public Relations: Evidence from a Scale Development Study" (paper represented at the International Association for Business and Society Annual Conference, Victoria BC, Canada, June 28-30, 2002); Mudassar H. Shah and Xianhong Chen, "Relational Corporate Social Responsibility: Public Relations Implications in Culturally Confucius China," International Journal of Business and Social Science 1(3) (2010); Jacquie L'etang, "'Radical PR'- Catalyst For Change or An Aporia?," The International Journal of Communication Ethic 6(2) (2009); Zuzana Lusnakova, "Corporate Social Responsibility As Part of Public Relations and Firm Development," Polityki Europejskie Finanse I Marketing 5(54) (2014).

3 James E. Grunig, "Yönetimde Mükemmelik Nedir?," trans. Elif Ozsayar, in Halkla İlişkilerde ve İletişim Yönetiminde Mükemmelik, ed. James E. Grunig, (Istanbul: Rota, 2005); Krishnamurty Sriramesh and Dejan Vercic, "A Theoretical Framework For Global Public Relations Research and Practice," in The Global Public Relations Handbook, ed. Krishnamurty Sriramesh and Dejan Vercic (New York: Routledge, 2009).

4 Vercic, et al. "Global and Specific Principles Of Public Relations: Evidence from Slovenia," in International public relations: A comparative analysis, ed. Hugh M. Culbertson and Ni Chen (Mahwah, NJ: Lawrence Erlbaum Associates, 1996).

5 Sriramesh and Vercic, "A Theoretical Framework."

6 Jeonic-Nam Kim and Krishnamurty Sriramesh, "Activism and Public Relations," in The Global Public Relations Handbook: Theory, Research and Practice, ed. Krishnamurty Sriramesh and Dejan Vercic (New York: Routledge, 2009).

7 Ronel Rensbug, "Public Relations in South Africa: From Rhetoric To Reality," in The global Public Relations Handbook, ed. Krishnamurty Sriramesh and Dejan Vercic (Mahwah, NJ: Lawrence Erlbaum Associates, 2003); Sandra L. Braun, "The Effects of the Political Environment on Public Relations in Bulgaria," Journal of Public Relations Research 19(3) (2007); Krishnamurty Sriramesh, "The Relationship Between Culture and Public Relations," in The Global Public Relations Handbook, ed. Krishnamurty Sriramesh and Dejan Vercic (New York: Routledge, 2009); F. Brooke Liu and B. Abbey Levenshus, "Public Relations Professionals' Perspectives On The Communication Challenges and Opportunities They Face in The U.S. Public Sector," PRism 7(1) (2010).

8 "General Information about Azerbaijan Republic", accessed February 11, 2014, http: / / www. mfa.gov.az $/$ ?language $=$ az\&options $=$ content $\&$ id $=8$, [access date: 11.11.2014] 
9 Ramil Meherremov, Ictimaiyyetle Elaqeler Isi: Public Relations (Baku: ?, 2002), accessed February 10, 2014, http: / / kitabxana.net / files / books / file/1362763368.pdf

10 E. James Grunig and A. Larissa Grunig, “The Relationship Between Public Relations And Marketing In Excellent Organizations: Evidence From The IABC Study," Journal of Marketing Communications 4 (1998); L. Michael Kent and Maureen Taylor, "How Intercultural Communication Theory Informs Public Relations Practice in Global Settings," in Public Relations In Global Cultural Contexts, ed. Nilanjana Bardhan and C. K. Weaver (New York: Routledge, 2010); Cesar Garcia, "Clientlesim, Economic Structure, and Public Relations In Southern Europe: An Example Of Diversity In The Western World," Public Relations Journal 7(2) (2013).

11 Sahar Khamis and L. Elizabeth Toth, "International Public Relations: An American Perspective," (paper presented in Tripods, Barcelona, 2009), 36.

12 "Economy of Azerbaijan Republic," accessed February 11, 2014, http://www.mfa.gov.tr/ azerbaycan-ekonomisi.tr.mfa

13 N. Osman Aras, et al. "Azerbaycan'ın Enerji Kaynakları Gelirlerinin Ülke Ekonomisine Katkısı,” Çankırı Karatekin Üniversitesi Uluslararası Avrasya Strateji Dergisi 2(2) (2013), 4.

14 Abulfez Suleymanov, "Ekonomik ve Sosyo-Kültürel Degisim Süreci Icerisinde Azerbaycan Toplumunun Bazı Meseleleri," İstanbul Üniversitesi Sosyoloji Konferansları Dergisi, 29 (2004), 51.

15 Meherremov, Ictimaiyyetle Elaqeler, 48.

16 Sriramesh, "The Relationship," 48.

17 Sema Becerikli, Uluslararası Halkla İlişkiler, (Ankara: Nobel, 2005).

18 Greg Leichty, "The Cultural Tribes of Public Relations," Journal of Public Relations Research 15(4) (2003); Kent and Taylor, "How Intercultural."; Krishnamurty Sriramesh and John White, "Toplum Kültürü Ve Halkla İlişkiler," trans. Elif Ozsayar, in Halkla İlişkilerde ve İletişim Yönetiminde Mükemmelik, ed. James E. Grunig (Istanbul: Rota, 2009); D. Marianne Sison, “Whose Cultural Values? Exploring Public Relations' Approaches To Understanding Audiences," Prism 6(2) (2009); Chinenye Nwabueze et al., "Cross-Cultural Research Relevance in Public Relations: An Analytical Appraisal," IOSR Journal of Business and Management (IOSRJBM) 3(6) (2012).

19 Ministery of Foreign Affairs Azerbaijan, "General Information about Azerbaijan Republic," accessed February 11, 2014, http: / / www.mfa.gov.az / ?language=az\&options=content\&id=8

20 Vafa Hasanova, “Tek Türk Alfabesi," Turan-Sam 4(13) (2012), 6.

21 Dejan Vercic, "Mass Media and Public Relations," in The Global Public Relations Handbook: Theory, Research and Practice, ed. Krishnamurty Sriramesh and Dejan Vercic, (New York: Routledge, 2009).

22 Q. Konul Niftelıyeva, "Islahatlar Dövrü Azerbaycan Kütlevi İnformasiya Vasitelerinin Tipoloji Strukturu," Bakı Üniversiteti Xeberleri, 2 (2015), 211-212. 
23 Q. Afaq Ezimova, "Edebi-Bedii Jurnallarımız ve Azerbaycan Reallıqları," Bakı Universitet Xeberleri, 2 (2005); Faiq Husiyev, Xarici Ölkelerde Azerbaycan Metbuatı: 1990-2005ci Iller, (Baku: “OL” MMC, 2014).

24 Leyla Budak, "Bağımsızlığının Yirminci Yılında Azerbaycan Medyasının Genel Durumu," Ege Ünivesitesi. Edebiyat Fakültesi\&iletişim Fakültesi Uluslararası Sosyal, Kültürel, Siyasal, Ekonomik ve Iletişim Araştırmaları Dergisi 6 (2011), 5.

25 Ayhan Erdal and Eyüp Zengin, "Reklamcılık ve Azerbaycan'da Reklamcılığın Gelişimi," Journal of Qafqaz University 7 (2001).

26 Vefalı Enserov, “Azerbaycan'da Özel Radyo ve Televizyon Yayıncılığı,”.AJII-e: Online Academic Journal of Information Technology 4(11) (2013), 75.

27 A. Namik Heyderov, "Dr. J. Gregor Payne Delivers Seminar on Media Relations and Media Ethics," february 19, 2004, accessed January 5, 2014, http:/ / www.transparency.az/transpfiles/klim5.pdf

28 Meherremov, Ictimaiyyetle Elaqeler, 52-55.

29 Grunig, “Yönetimde Mükemmelik," 258.

30 Basak Solmaz, “İşletmelerin Değişen Konumuyla Gelişen Kurumsal Sosyal Sorumluluk Bilinci ve Turkcell'in Desteklediği 'Çağdaş Türkiye'nin Çağdaş Kızları' Projesinin Genel Bir Değerlendirilmesi," Selçuk İletişim Dergisi 4(1) (2005).

31 Clark, "Halkla İlişkilerde."; Shah and Chen, "Relational Corporate."

32 E. James Grunig and T. Tedd Hunt, Managing Public Relations, (New York: Holt, Rinehart and Winston, 1984).

33 Shah and Chen, "Relational Corporate," 119.

34 Black and Hartel, “The Relationship.”; Mette Morsing and Majken Schultz, "Corporate Social Responsibilty Communication: Stakeholder Information, Response, and Involvement Strategies," Business Ethics: A European Review 15(4) (2006).

35 Konrad Adenauer Foundation 2013 publication, accessed February 9, 2014. http:/ / cesd.az/ new/wpcontent/uploads/2011/05/CSR_Research_Paper_CESD_KAS.pdf, 29.

36 Nilgun Koklu, “Örnek Olay Çalışma Metotları," Eğitim Bilimleri Fakültesi Dergisi 27(2) (1994).

37 Louis Cohen, Lawrence Manion and Keith Morrison, Research Methods in Education (New York: Routledge, 2005).

38 B. Sharan Merriam, Qualitative Research: A Guide to Design and Implementation (San Francisco: John Wiley and Sons, 2009), 40-41.

39 K. Robert Yin, Case Study Research: Design and Methods (London: Sage Publications, 2003).

40 “Azercell Social Project", accessed February 10, 2014, http:/ / www.azercell.com/az/company/sustainability/project_form/social/ 
$70<$ ilef dergisi

41 "Azercell Social Project", accessed February 10, 2014,

http:/ / www.azercell.com/az/company/sustainability/ project_form/social /

42 Azerbaijan Child Hepline Service, accessed February 10, 2014, http:/ / www.childhelpline. az/index.php/az/ 